\title{
Visual Symptoms of Water and Nitrogen Deficiency in Leaves of Clove Basil (Ocimum gratissimum L.)
}

\author{
Crisálida M. Vilanova ${ }^{1}$, Kátia P. Coelho ${ }^{2}$, Tássio R. S. A. Luz ${ }^{1}$, Daniella P. B. Silveira ${ }^{1}$, Denise F. Coutinho ${ }^{1}$ \\ \& Emanoel G. Moura ${ }^{2}$ \\ ${ }^{1}$ Department of Pharmacy, Federal University of Maranhão, São Luís, Maranhão, Brazil \\ ${ }^{2}$ Department of Agricultural Engineering, State University of Maranhão, São Luís, Maranhão, Brazil \\ Correspondence: Emanoel G. Moura, Department of Agroecology, State University of Maranhão, s/n, Tirirical, \\ São Luís, Maranhão, 65054-970, Brazil. Tel: 55-98-2016-8152. E-mail: egmoura@elointernet.com.br
}

Received: July 12, $2018 \quad$ Accepted: August 11, $2018 \quad$ Online Published: October 15, 2018

doi:10.5539/jas.v10n11p149 URL: https://doi.org/10.5539/jas.v10n11p149

\begin{abstract}
Ocimum gratissimum L. (clove basil) is an annual herb of the Lamiaceae family, widely cultivated as a plant used in cooking and medicine worldwide. There is no information on the visual symptoms of the effects of greater or lesser water irrigation and nitrogen fertilization on the leaves of this species. There is no information on the visual symptoms of the effects of greater or lesser water irrigation and nitrogen fertilization $(\mathrm{N})$ on the leaves of this species. The effects of different water application rates, $60 \%\left(\mathrm{I}_{60}\right), 70 \%\left(\mathrm{I}_{70}\right), 80 \%\left(\mathrm{I}_{80}\right), 90 \%\left(\mathrm{I}_{90}\right)$, $100 \%\left(\mathrm{I}_{100}\right)$ and $110 \%\left(\mathrm{I}_{110}\right)$ of field capacity $(\mathrm{FC})$, and nitrogen fertilization, $0\left(\mathrm{~N}_{0}\right), 40\left(\mathrm{~N}_{2}\right), 80\left(\mathrm{~N}_{4}\right)$ and $160\left(\mathrm{~N}_{8}\right)$ $\mathrm{kg}$ of nitrogen/ha, on the leaves of this species were studied. The experiment was carried out for 60 days in a greenhouse in a completely randomised design with three replicates. Water stress was determinant for the appearance of leaves with wilted and stains. Symptoms of necrosis, apical necrosis, abscission and chlorosis were correlated only with $\mathrm{N}$ stress. This study suggests that the leaves of Ocimum gratissimum present better acclimatization with irrigation above the field capacity associated with high dose of $\mathrm{N}\left(\mathrm{I}_{10} \mathrm{~N}_{8}\right)$ and that satisfactorily support the reduction of up to $70 \% \mathrm{FC}$ with the use of $40 \mathrm{~kg}$ of N/ha in their production without presenting any visual symptoms.
\end{abstract}

Keywords: field capacity, nutrient, water stress, fertilization

\section{Introduction}

Agricultural research and development over the past 50 years has focused primarily on increasing productivity through increased use of inputs, resulting in environmental costs such as water and soil pollution. This has led to the pursuit of the development of sustainable production practices to meet the growing demand of quality, locally produced, regionally specialized and with minimal use of chemical inputs in production to reduce environmental impact (Stefanelli, Goodwin, \& Jones, 2010).

The reduction of water use in horticulture, maintaining the quality and yield of the product contributes to a reduction of groundwater contamination by excess nutrients, growth regulators, nitrates, pesticides (Agrawal, Pandey, \& Sharma, 2010), but, also, this has become a critical issue, due to the scarcity of this resource in the world, not only in arid and semi-arid areas as well as in humid regions of the planet (Evans \& Sadler, 2008).

Nitrogen is one of the most abundant mineral elements in plant species and is essential for the normal growth and development of plants, since it is involved in the formation of important molecules and organelles such as proteins, nucleic acids and chloroplasts (Taiz, Zeiger, Moller, \& Murphy, 2014).

There are two distinct sources of $\mathrm{N}$ for leaf growth: the $\mathrm{N}$ of the uptake and assimilation that is transferred directly to the growing leaf and the $\mathrm{N}$ of the redistribution of organic compounds (recyclable). Nitrogen fertilization has multiple direct and indirect effects on plant $\mathrm{N}$ metabolism. In particular, it modifies the $\mathrm{N}$ content of young leaves, leaf senescence and the dynamics of light distribution within the growing canopies by increasing $\mathrm{N}$ availability directly transferable to leaf growth and by influencing the availability of recyclable $\mathrm{N}$ (Lehmeier, Wild, \& Schnyder, 2013).

However, nitrogen fertilization must be carried out in a judicious way due to the various forms of losses of this nutrient (erosion, leaching and volatilization), which can cause, mainly, water pollution, which makes it 
considered one of the most difficult to be managed, due to the diverse transformations that it undergoes in the soil (Maqsood et al., 2016).

Irrigation management and soil fertility are generally done to fully meet the demand of plants for the purpose of maximizing production. However, studies have demonstrated that the management should contribute to the maximum economic yield and not to the maximum productivity of the crop (Perez, 2015; Azevedo, Bomfim, Nascimento Neto, Viana, \& Vasconcelos, 2016; Wang \& Xing, 2017). Therefore, fully satisfying the nutrient and water needs of the crops is not sufficient to achieve higher economic returns, and it is necessary to observe these indices in order to minimize costs and optimize yield, which are influenced by such factors (Mancosu, Snyder, Kyriakakis, \& Spano, 2015; Moswetsi, Fanadzo, \& Ncube, 2017). Thus the adequate supply of water and nutrients is essential.

Ocimum gratissimum L. (clove basil), a dicotyledonous shrub plant, which belongs to the Lamiaceae family, have been used in applications in the pharmaceutical, cosmetic and food industries. This plant has several scientifically proven therapeutic abilities, such as a hypoglycaemic agent (Casanova, Gu, Costa, \& Jeppesen, 2017); antioxidant (Hzounda et al., 2016); antifungal (Nguefack et al., 2009); antibacterial (Bonou et al., 2016); and in treating hepatopathies (Chiu et al., 2014), among others. It is also popularly used in herbal medicine for treating several diseases, such as upper respiratory tract infection, fever, piles, cough, diarrhoea and pneumonia (Pandey, 2017).

Despite several studies dealing with the effect of water and nutrient stress on Ocimum gratissimum (Osuagwu, Edeoga \& Osuagwu, 2010; Ormeño \& Fernandez, 2012; Ade-Ademilua, Obi, \& Craker, 2013), information about the influence of multiple and interactive stress factors commonly experienced by plants in the field is scarce. Moreover, there are no studies on the visual impact of water and nitrogen deficiency on Ocimum gratissimum leaves. For this reason, the objective of this work was to study the effect of water stress and different nitrogen doses and their interaction on the development of visual symptoms in leaves of this plant species.

\section{Method}

\subsection{Installation and Design of the Experiment}

The study was carried out in 2016 (September-November) in a greenhouse at Maranhão State University, São Luís, Brazil $\left(2^{\circ} 30^{\prime} \mathrm{S}\right.$ and $\left.44^{\circ} 18^{\prime} \mathrm{W}\right)$. While conducting the experiment, the mean greenhouse temperature was $28{ }^{\circ} \mathrm{C}$, with maximum temperature of $33.8^{\circ} \mathrm{C}$ and minimum temperature of $24.9^{\circ} \mathrm{C}$. The mean relative humidity was $71.4 \%$, with the maximum and minimum relative humidity of $77.3 \%$ and $68.2 \%$, respectively. The soil in the study was classified as Ultisol (USDA-NRCS, 1999) and its chemical properties were determined (Carter \& Gregorich, 2008), as follows in Table 1:

Table 1. Chemical properties of the soil used in the experiments

\begin{tabular}{lll}
\hline Parameter & Unit & Value \\
\hline $\mathrm{Ca}^{2+}$ & $\mathrm{mmol} / \mathrm{dm}^{3}$ & 32.0 \\
$\mathrm{Mg}^{2+}$ & $\mathrm{mmol}_{\mathrm{c}} / \mathrm{dm}^{3}$ & 49.0 \\
$\mathrm{~K}^{+}$ & $\mathrm{mmol}_{\mathrm{c}} / \mathrm{dm}^{3}$ & 3.30 \\
$\mathrm{Al}^{3+}$ & $\mathrm{mmol}_{\mathrm{c}} / \mathrm{dm}^{3}$ & 1.00 \\
$\mathrm{H}^{+}$ & $\mathrm{mmol}_{\mathrm{c}} / \mathrm{dm}^{3}$ & 4.00 \\
$\mathrm{Na}^{+}$ & $\mathrm{mmol}_{\mathrm{c}} / \mathrm{dm}^{3}$ & 5.70 \\
$\mathrm{SB}$ & $\mathrm{mmol}_{\mathrm{c}} / \mathrm{dm}^{3}$ & 90.0 \\
$\mathrm{CTC}$ & $\mathrm{mmol} / \mathrm{dm}^{3}$ & 95.0 \\
$\mathrm{MO}$ & $\mathrm{mg} / \mathrm{dm}^{-3}$ & 20.0 \\
$\mathrm{P}$ & $\mathrm{mg} / \mathrm{dm}^{-3}$ & 25.0 \\
$\mathrm{Ph}(\mathrm{CaCl}$ & & 8.30 \\
$\mathrm{Na}$ & & 6.00 \\
$\mathrm{Al}^{3+} / \mathrm{Cl}^{3+}+\mathrm{SB}$ & $\%$ & 1.10 \\
$\mathrm{~V}$ & $\%$ & 94.7 \\
\hline
\end{tabular}




\subsection{Conduction of the Greenhouse Experiment}

The experiment was conducted in plastic pots with a capacity of $10 \mathrm{dm}^{3}$ in a completely randomised design with three replicates, a $5 \times 3$ factorial arrangement, which consisted of five water regimes, taking into a account the percentage of the soil field capacity and three nitrogen doses. The pots were filled uniformly with $10 \mathrm{~kg}$ of sieved and homogenised soil. Four seeds of Ocimum gratissimum were sown in each vase. To ensure satisfactory development, all plants were fully irrigated until thinning 14 days after sowing, when water application rate and nitrogen fertilization treatments were initiated by keeping two plants per pot. A total of $60 \%\left(\mathrm{I}_{60}\right), 70 \%\left(\mathrm{I}_{70}\right), 80 \%$ $\left(\mathrm{I}_{80}\right), 90 \%\left(\mathrm{I}_{90}\right)$ and $100 \%\left(\mathrm{I}_{100}\right)$ of field capacity $(\mathrm{FC})$ was used. The volumetric soil moisture content at the FC was determined collecting three replicates of soil samples before the planting in volumetric rings with a $100 \mathrm{~cm}^{3}$ capacity. The available water capacity was calculated from the difference of soil mass between $-10 \mathrm{kPa}$ (field capacity) and $-1500 \mathrm{kPa}$ (permanent wilting point). The samples were saturated, weighed, placed on a tension table and equilibrated at $-10 \mathrm{kPa}$ (Thomasson, 1978). This volumetric soil moisture content was considered to $100 \% \mathrm{FC}\left(\mathrm{I}_{100}\right)$. The $\mathrm{I}_{100}$ treatments were used as controls for adding water at the other water application rate. In order to maintain soil in different water regimes, all pots were weighed and adjusted daily at the same time each day. Nitrogen (as urea source) was applied to roots in doses of 0.0, 2.0 and $4.0 \mathrm{~g}$ of nitrogen $(\mathrm{N})$ per pot, which correspond to $0\left(\mathrm{~N}_{0}\right), 40\left(\mathrm{~N}_{2}\right)$ and $80\left(\mathrm{~N}_{4}\right) \mathrm{kg}$ of $\mathrm{N} / \mathrm{ha}$, in four equal fractions at $0,15,30$ and 45 days after emergence (DAE). We also evaluated an additional treatment with $110 \% \mathrm{FC}\left(\mathrm{I}_{110}\right)$ and $8.0 \mathrm{~g}$ of N per pot, which corresponds to $160 \mathrm{~kg}$ of $\mathrm{N} / \mathrm{ha}\left(\mathrm{N}_{8}\right)$. All plants were observed daily up to $60 \mathrm{DAE}$, when they showed the greatest vegetative growth (i.e., in the inflorescence). A voucher specimen (MAR-9037) was deposited in the Herbarium of Maranhão, Biology Department, Federal University of Maranhão, Brazil.

\subsection{Evaluation of Morphometric Parameters}

All plants were observed daily up to 60 DAE. During this period we verified the appearance of possible visual symptoms and their evolution in Ocimum gratissimum leaves due to water stress and the different levels of nitrogen fertilization.

\subsection{Statistical Analyses}

Data were analysed using the R (R Core Team, 2015) and Sisvar 5.6 (Ferreira, 2011) software. Analysis of variance (ANOVA) was performed and means were compared using the LSD test at 5\% significance level. All the graphics were done with Sigma Plot 10.0 software (Systat Software, San Jose, CA).

\section{Results and Discussion}

The leaves of Ocimum gratissimum under water and nitrogen stress showed symptoms of wilting, stains, abscission, chlorosis, necrosis and apical necrosis (Figures 1A-1C), however without significant relevance on the appearance of these symptoms in the interaction of these two resources.

The water stress was determinant for the appearance of wilted and stained leaves in Ocimum gratissimum $(\mathrm{p}<$ $0.05)$, showing no statistical relevance for the symptoms of necrosis, apical necrosis, abscision and chlorosis ( $\mathrm{p} \geq$ $0.05)$ (Figure 2). 

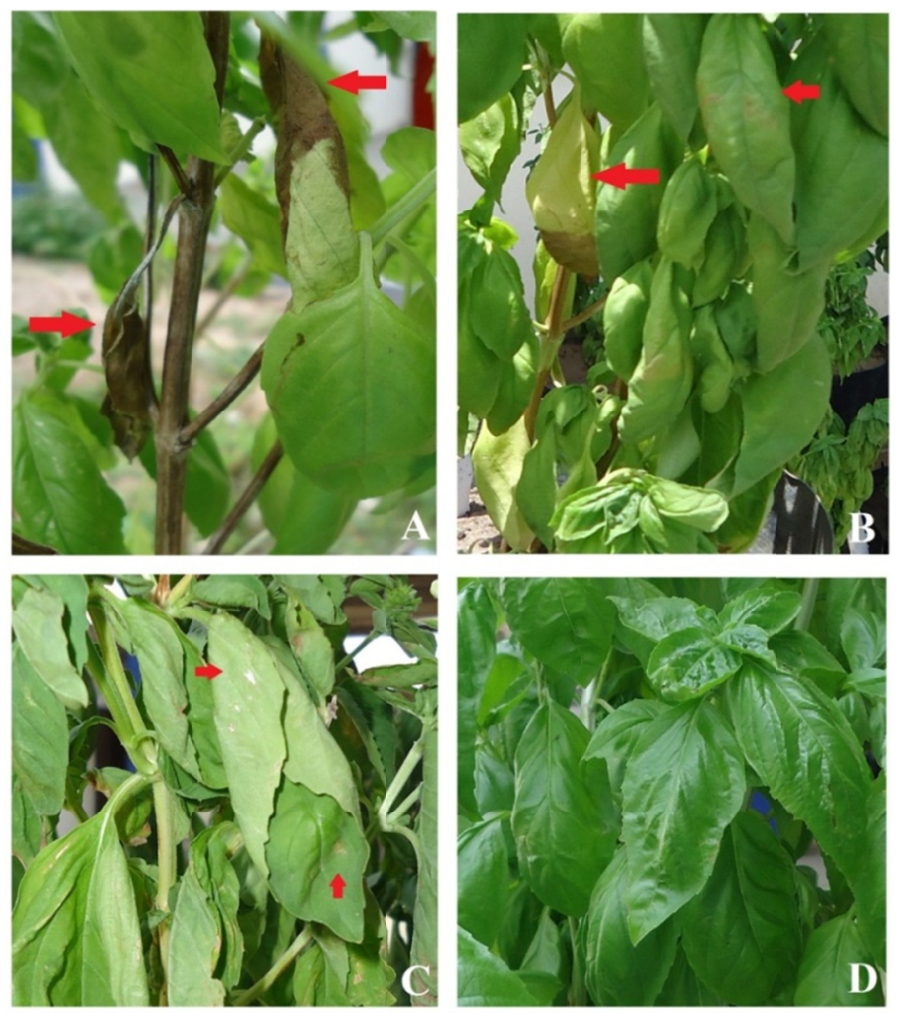

Figure 1. Leaves of Ocimum gratissimum L. submitted to treatments $\mathrm{I}_{100} \mathrm{~N}_{0}$ (A) with necrosis (long arrow), $\mathrm{I}_{100} \mathrm{~N}_{2}$ (B) with chlorosis and apical necrosis (long arrow) and spots (short arrow) and $\mathrm{I}_{60} \mathrm{~N}_{4}(\mathrm{C}$ ) with wilting and spots (short arrow) due to water stress and nitrogen stress compared to healthy leaves of the $\mathrm{I}_{110} \mathrm{~N}_{8}$ treatment (D)

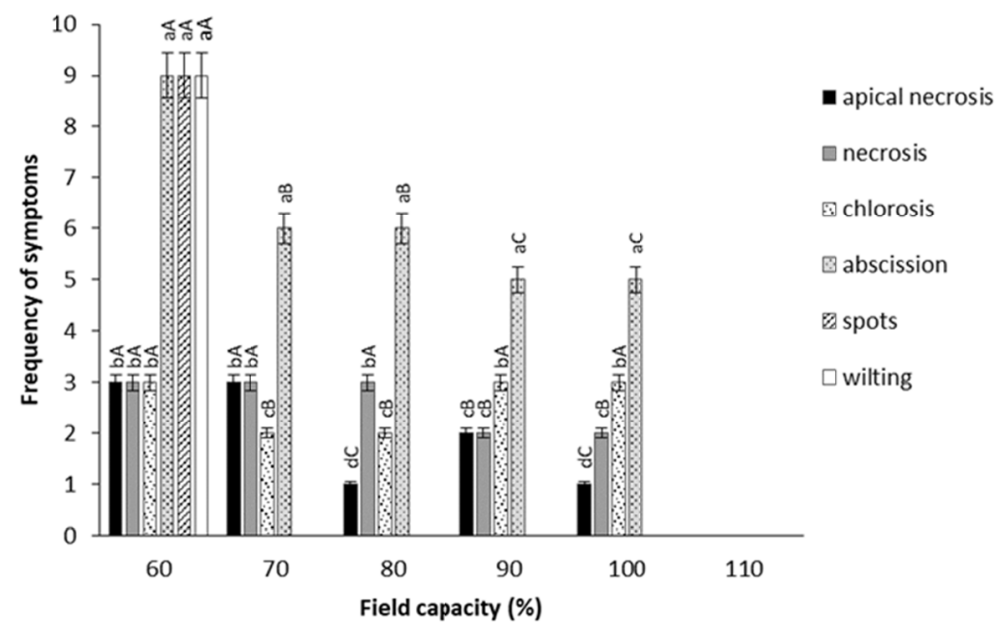

Figure 2. Visual symptoms of leaves of Ocimum gratissimum L. submitted to different levels of field capacity. Different letters (lowercase letters for symptoms in each field capacity and uppercase letters for each symptom between treatments) indicate significant difference at the 5\% level by LSD test

Taiz et al. (2014) report that turgor reduction is the most early biophysical significant effect of water stress and, consequently, leaf expansion and rod development, which depend on turgor, are more sensitive and are the first perceived effects in a submitted vegetable to this adverse situation. The observation of wilted leaves in Ocimum gratissimum as the first response to water stress was consistent with this physiological behavior. On the other hand, abscisic acid produces changes that confer to the vegetable the capacity to maintain the cellular turgor to support the dehydration (Farooq, Wahid, Kobayashi, Fujita, \& Basra, 2009) and according to Kosma et al. (2009) there is a delay in wilting in plants acclimatized to water stress in comparison with previously unacclimatized 
plants. For Kosma et al. (2009) the induction of cutaneous lipids may be important in this acclimation because it is associated with reduced permeability to the cuticle, an adaptation that can limit transpiration and delay the appearance of water stress during prolonged drought. Ocimum gratissimum presented wilted leaves only in $\mathrm{I}_{60}$ treatment (Figure 1C), which in our study was very close to the permanent wilting point, with satisfactory acclimation to water reduction up to $\mathrm{I}_{70}$ treatment.

According to a survey by Desprez-Loustau, Marcais, Nageleisen, Piou, and Vannini, (2006) and Oliva, Stenlid, and Martínez-Vilalta, (2014) the increase of water stress is related to the appearance and increase of the severity of fungal diseases in plants. In our study, Ocimum gratissimum showed stains on its leaves only in the treatment at $\mathrm{I}_{60}$ (Figure $1 \mathrm{C}$ and Figure 2) and a pathogenic infection may be an explanation for the appearance of these patches probably due to the decrease of plant defenses by water stress.

Symptoms of necrosis, apical necrosis, abscission and chlorosis were correlated only with nitrogenous variation $(\mathrm{p}<0.05)$, differing the type of symptom according to the amount of $\mathrm{N}$ added. The variation in nitrogen fertilization was not a relevant factor for the wilting and stain observed in this study ( $p \geq 0.05)$ (Figure 3 ).

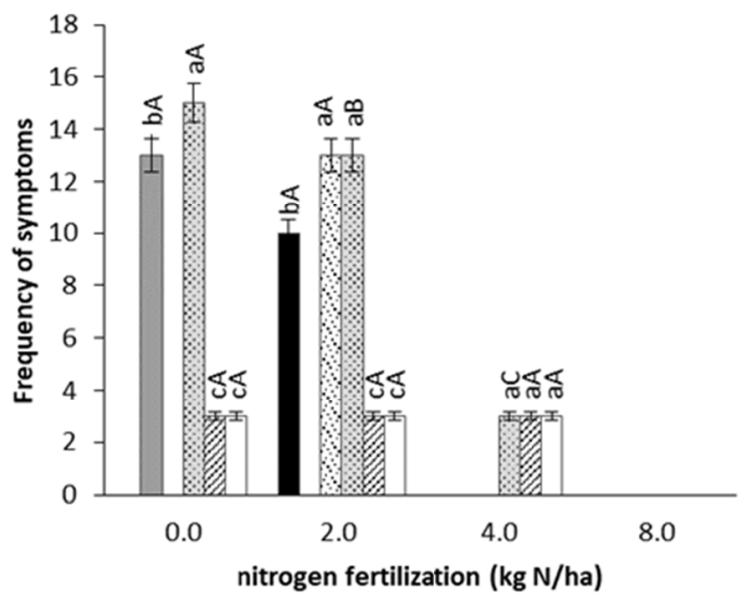

apical necrosis
$\square$ necrosis
$\square$ chlorosis
$\square$ abscission
$\square$ spots
$\square$ wilting

Figure 3. Visual symptoms of leaves of Ocimum gratissimum L. submitted to different levels of nitrogen fertilization. Different letters (lowercase letters for symptoms in each nitrogen dose and uppercase letters for each symptom between treatments) indicate significant difference at the $5 \%$ level by LSD test

Ocimum gratissimum was more sensitive to nitrogen variation than to water stress. When comparing treatments $\mathrm{N}_{0}, \mathrm{~N}_{2}$ and $\mathrm{N}_{4}$, the presence of chlorosis was statistically significant $(\mathrm{p}<0.05)$ only in $\mathrm{N}_{2}$ treatment (Figure 3). Chlorosis is an initial symptom typical of $\mathrm{N}$ deficiency and this is due to the $\mathrm{N}$ is easily redistributed by the plant of the older and intermediate leaves to the new organs or leaves via phloem, in order to guarantee its growth and development in the face of the scarcity of this nutrient in the environment (Lima et al., 2015; Maillard et al., 2015; Viegas et al., 2018).

There was no statistical difference regarding the presence of abscission in $\mathrm{N}_{0}$ and $\mathrm{N}_{2}$ treatments, but there were between these treatments and $\mathrm{N}_{4}$ treatment. The studies of Ren et al. $(2011,2013)$ have shown that leaf longevity is reduced by increased water and $\mathrm{N}$ availability, isolated and in interaction, mainly by altering the production of ethylene, an endogenous plant hormone involved in the control of senescence and leaf abscission. On the other hand, for Sirousmehr, Arbabi, and Asgharipour, (2014) foliar abscission is a long-term adaptation of the vegetable to the water limitation, which also stimulates the plant's synthesis and sensitivity to ethylene. However, the studies by Hanaoka et al. (2002) with the genome of Arabidopsis thaliana found increased senescence with $\mathrm{N}$ deficiency from autophagy regulation, which may explain our results obtained with Ocimum gratissimum. Autophagy contributes significantly to the efficiency and productivity of nitrogen use of the plant and is especially necessary during leaf senescence and when plants are grown under low availability of nitrate, as it contributes to the maintenance of cellular homeostasis, C:N balance and redox metabolism (Masclaux-Daubresse, 2016).

Necrosis and apical necrosis were statistically significant $(\mathrm{p}<0.05)$ only in $\mathrm{N}_{0}$ treatment in relation to $\mathrm{N}_{2}$ and $\mathrm{N}_{4}$ treatments (Figure 3). It is believed that these two symptoms occurred due to the use of $\mathrm{N}$ of the plant by pathogens, as there were stains indicative of fungal diseases in $\mathrm{I}_{60}$ treatment, as mentioned previously. Apical leaf 
necrosis is a physiological process related to the dynamics of $\mathrm{N}$ in the leaf. According to Van Den Berg et al. $(2007,2008)$ pathogens use foliar nutrients and can thus accelerate apical physiological necrosis, and provided that the benefits of reducing the disease by early apical necrosis outweigh the cost of loss of healthy leaf material, as in the case of high availability of nutrients, the plant can use necrosis as a defense against some diseases, because biotrophic pathogens do not grow on necrotic foliar material. Although necrosis symptoms were not correlated with water stress in our study, Lund, Stall, and Klee, (1998) and Bashan (1994) attributed apical leaf necrosis to the stimulus in the production of ethylene by infection by pathogens and report that this necrosis can also occur due to cellular damage induced by the intracellular growth of certain pathogenic species due to water stress.

Generally, maintaining a soil with moisture above field capacity for long periods, as with $\mathrm{I}_{110}$ treatment, leads to a decrease in soil aeration because the pores will be filled with water instead of oxygen and water will block diffusion of gas from the atmosphere to the ground (Chen et al., 2011). This may cause several symptoms in plants, but the cause of plant damage in soils is often questioned and the literature suggests that it is more related to the production of toxic substances than the oxygen deficiency in the roots themselves (Morales-Olmedo, Ortiz, \& Sellés, 2015). However, there was no symptom of stress in the I110N8 treatment (Figure 1D), which may suggest a better acclimatization by the co-limitation between irrigation above field capacity and high nitrogen dose.

Albarenque, Basso, Caviglia, and Melchiori (2016) used the concept of water-nitrogen co-limitation to explore maize response to availability of resources. Co-limitation is operationally identified when the output response of a biological system (e.g. plant or population growth) to two or more inputs is greater than its response to each factor in isolation. Interactions between water and nitrogen influence processes ranging from the ecosystem to the molecular level. Water-nitrogen interactions affect crop yield, leaf stoichiometry, photosynthesis, senescence and root-to-shoot translocation. The hypothesis of Bloom et al. (1985) that plant production is maximised when it is equally limited by all resources, is reworded in terms of co-limitation and formulated in quantitative terms, i.e., for a given intensity of aggregate stress, plant production is proportional to degree of resource co-limitation.

According to Ågren, Wetterstedt, and Billberger (2012), co-limitation occur at very strict nutrient ratios (optimum ratios) and the rate control on growth by one nutrient depends on the rate control by another nutrient of another process, where two nutrients both limit growth, but because of the multiple limitation of resources, the co - limitation will always exist and plants should always be driven towards the point of optimum nutrient ratios, where it is difficult to know whether the optimum is actually a single value or rather a range of ratios and a consequence of such balancing of resources is a variable root:shoot allocation.

\section{Conclusion}

There was a correlation between the occurrence of necrosis, apical necrosis, abscision and chlorosis with the decrease of nitrogen and the stain and wilting with water deficit. Ocimum gratissimum has higher tolerance of to water stress and its greater sensitivity to nitrogen variation.

\section{References}

Ade-Ademilua, E. O., Obi, H. O., \& Craker, L. E. (2013). Growth and essential oil yield of african basil, Ocimum gratissimum, under light and water stress. Journal of Medicinally Active Plants, 1, 143-149.

Agrawal, A., Pandey, R. S., \& Sharma, B. (2010). Water pollution with special reference to pesticide contamination in India. Journal of Water Resource and Protection, 2, 432-448. https://doi.org/10.4236/ jwarp.2010.25050

Ågren, G. I., Wetterstedt, J. Å. M., \& Billberger, M. F. K. (2012). Nutrient limitation on terrestrial plant growth-Modeling the interaction between nitrogen and phosphorus. New Phytology, 194, 953-960. https://doi.org/ 10.1111/j.1469-8137.2012.04116.x

Albarenque, S. M., Basso, B., Caviglia, O. P., \& Melchiori, R. J. M. (2016). spatio-temporal nitrogen fertilizer response in maize: field study and modeling approach. Agronomy Journal, 108, 1-13. https://doi.org/10.2134/ agronj2016.02.0081

Azevedo, B. M. de, Bomfim, G. V. do, Nascimento Neto, J. R. do, Viana, T. V. D. A., \& Vasconcelos, D. V. (2016). Idepths and yield response factor in the productive phase of yellow melon. Revista Brasileira de Fruticultura, 38, 1-13. https://doi.org/10.1590/0100-29452016802

Bashan, Y. (1994). Symptom expression and ethylene production in leaf blight of cotton caused by Alternaria macrospora and Alternaria alternata alone and in combination. Canadian Journal of Botany, 72, 1574-1579. https://doi.org/10.1139/b94-194 
Bloom, A. J., Chapin, F. S., \& Mooney, H. A. (1985). Resource limitation in plants-an economic analogy. Annual Review of Ecology and Systematics, 16, 363-392. https://doi.org/10.1146/annurev.es.16.110185. 002051

Bonou, J., Baba-Moussa, F., Noumavo, P. A., Ahouandjinou, H., Adéoti, K., Métognon, I., ... Baba-Moussa, L. (2016). Composition chimique et influence de differents tweens sur le pouvoir antimicrobien des huiles essentielles de Ocimum gratissimum, Ocimum basilicum, Laurus nobilis et Melaleuca quinquenervia. European Scientific Journal, 12, 162-171. https://doi.org/10.19044/esj.2016.v12n27p162

Carter, M. R., \& Gregorich, E. G. ( 2008). Soil sampling and methods of analysis (2nd. ed.) Canadian Society of Soil Science, Taylor \& Francis Group, LLC, Boca Raton.

Casanova, L. M., Gu, W., Costa, S. S., \& Jeppesen, P. B. (2017). Phenolic substances from Ocimum species enhance glucose-stimulated insulin secretion and modulate the expression of key insulin regulatory genes in mice pancreatic islets. Journal of Natural Products, 80, 3267-3275. https://doi.org/10.1021/acs.jnatprod. $7 \mathrm{~b} 00699$

Chen, X., Dhungel, J., Bhattarai, S. P., Torabi, M., Pendergast, L., \& Midmore, D. J. (2011). Impact of oxygation on soil respiration, yield and water use efficiency of three crop species. Journal of Plant Ecology, 4, $236-248$. https://doi.org/10.1093/jpe/rtq030

Chiu, Y.-W., Chao, P.-Y., Tsai, C.-C., Chiou, H.-L., Liu, Y.-C., Hung, C.-C., ... Liu, J.-Y. (2014). Ocimum gratissimum is effective in prevention against liver fibrosis in vivo and in vitro. The American Journal of Chinese Medicine, 42, 833-852. https://doi.org/10.1142/S0192415X14500530

Desprez-Loustau, M.-L., Marçais, B., Nageleisen, L.-M., Piou, D., \& Vannini, A. (2006). Interactive effects of drought and pathogens in forest trees. Annals of Forest Science, 63, 597-612. https://doi.org/10.1051/ forest:2006040

Evans, R. G., \& Sadler, E. J. (2008). Methods and technologies to improve efficiency of water use. Water Resources Research, 44, 1-7. https://doi.org/10.1029/2007WR006200

Farooq, M., Wahid, A., Kobayashi, N., Fujita, D., \& Basra, S. M. A. (2009). Plant drought stress: Effects, mechanisms and management. Agronomy for Sustainable Development, 29, 185-212. https://doi.org/ 10.1051/ agro:2008021

Ferreira, D. F. (2011). Sisvar: A computer statistical analysis system. Ciência e Agrotecnologia, 35, $1039-1042$. https://doi.org/10.1590/S1413-70542011000600001

Hanaoka, H., Noda, T., Shirano, Y., Kato, T., Hayashi, H., Shibata, D., ... Ohsumi, Y. (2002). Leaf senescence and starvation-induced chlorosis are accelerated by the disruption of an Arabidopsis autophagy gene. Plant Physiology, 129, 1181-93. https://doi.org/10.1104/pp.011024

Hzounda, J. B. F., Jazet, P. M. D., Lazar, G., Raducanu, D., Caraman, I., Bassene, E., ... Lazar, I. M. (2016). Spectral and chemometric analyses reveal antioxidant properties of essential oils from four Cameroonian Ocimum. Industrial Crops and Products, 80, 101-108. https://doi.org/10.1016/j.indcrop.2015.09.077

Kosma, D .K., Bourdenx, B., Bernard, A., Parsons, E. P., Lu, S., Joubes, J., \& Jenks, M. A. (2009). The impact of water deficiency on leaf cuticle lipids of Arabidopsis. Plant Physiology, 151, 1918-1929. https://doi.org/ 10.1104/pp.109.141911

Lehmeier, C. A., Wild, M., \& Schnyder, H. (2013). Nitrogen stress affects the turnover and size of nitrogen pools supplying leaf growth in a grass. Plant Physiology, 162, 2095-2105. https://doi.org/10.1104/pp.113.219311

Lima, R. L. S. de, Gheyi, H. R., Azevedo, C. A. V. de, Sofiatti, V., Carvalho, G. S., \& Cazetta, J. O. (2015). Nutrient allocation among stem, leaf and inflorescence of jatropha plants. Revista Brasileira de Engenharia Agrícola e Ambiental, 19, 760-766. https://doi.org/10.1590/1807-1929/agriambi.v19n8p760-766

Lund, S. T., Stall, R. E., \& Klee, H. J. (1998). Ethylene regulates the susceptible response to pathogen infection in tomato. Plant Cell, 10, 371-382. https://doi.org/10.1105/tpc.10.3.371

Maillard, A., Diquélou, S., Billard, V., Lainé, P., Garnica, M., Prudent, M., ... Ourry, A. (2015). Leaf mineral nutrient remobilization during leaf senescence and modulation by nutrient deficiency. Frontiers in Plant Science, 6, 1-15. https://doi.org/10.3389/fpls.2015.00317

Mancosu, N., Snyder, R., Kyriakakis, G., \& Spano, D. (2015). water scarcity and future challenges for food production. Water, 7, 975-992. https://doi.org/10.3390/w7030975 
Maqsood, M. A., Awan, U. K., Aziz, T., Arshad, H., Ashraf, N., \& Ali, M. (2016). Nitrogen management in calcareous soils: Problems and solutions. Pakistan Journal of Agricultural Sciences, 53, 79-95. https://doi.org/ 10.21162/PAKJAS/16.4867

Masclaux-Daubresse, C. (2016) Autophagy controls carbon, nitrogen, and redox homeostasis in plants. Autophagy, 12, 896-897. https://doi.org/10.4161/auto.36261

Morales-Olmedo, M., Ortiz, M., \& Sellés, G. (2015). Effects of transient soil waterlogging and its importance for rootstock selection. Chilean Journal of Agricultural Research, 75, 45-56. https://doi.org/10.4067/ S0718-58392015000300006

Moswetsi, G., Fanadzo, M., \& Ncube, B. (2017). Cropping systems and agronomic management practices in smallholder farms in south africa: constraints, challenges and opportunities. Journal of Agronomy, 16, 51-64. https://doi.org/10.3923/ja.2017.51.64

Nguefack, J., Dongmo, J. B. L., Dakole, C. D., Leth, V., Vismer, H. F., Torp, J., ... Nkengfack, A. E. (2009). Food preservative potential of essential oils and fractions from Cymbopogon citratus, Ocimum gratissimum and Thymus vulgaris against mycotoxigenic fungi. International Journal of Food Microbiology, 131, 151-156. https://doi.org/10.1016/j.ijfoodmicro.2009.02.009

Oliva, J., Stenlid, J., \& Martínez-Vilalta, J. (2014). The effect of fungal pathogens on the water and carbon economy of trees: Implications for drought-induced mortality. New Phytologist, 203, 1028-1035. https://doi.org/10.1111/nph.12857

Ormeño, E., \& Fernandez, C. (2012). Effect of soil nutrient on production and diversity of volatile terpenoids from plants. Current Bioactive Compounds, 8, 71-79. https://doi.org/10.2174/157340712799828188

Osuagwu, G. G. E., Edeoga, H. O., \& Osuagwu, A. N. (2010). The influence of water stress (drought) on the mineral and vitamin potential of the leaves of Ocimum gratissimum L. Recent Research in Science and Technology, 2, 27-33.

Pandey, S. (2017). Phytochemical constituents, pharmacological and traditional uses of Ocimum gratissimum L. in tropics. Indo American Journal of Pharmaceutical Sciences, 4, 4234-4242.

Perez, M. R. (2015). Regulating farmer nutrient management: a three-state case study on the Delmarva Peninsula. Journal of Environment Quality, 44, 402-414. https://doi.org/10.2134/jeq2014.07.0304

R Core Team. (2015). R: A language and environment for statistical computing. R Foundation for Statistical Computing, Vienna, Austria. Retrieved from https://www.R-project.org/

Ren, H., Xu, Z., Zhang, W., Jiang, L., Huang, J., Chen, S., Wang, L., \& Han, X. (2013). Linking ethylene to nitrogen-dependent leaf longevity of grass species in a temperate steppe. Annals of Botany, 112, 1879-1885. https://doi.org/10.1093/aob/mct223

Ren, H., Xu, Z., Huang, J., Clark, C., Chen, S., \& Han, X. (2011). Nitrogen and water addition reduce leaf longevity of steppe species. Annals of Botany, 107, 145-155. https://doi.org/10.1093/aob/mcq219

Ruan, L., Wei, K., Wang, L., Cheng, H., Zhang, F., Wu, L., ... Zhang, C. (2016). Characteristics of $\mathrm{NH}_{4}^{+}$and NO$_{3}{ }^{-}$ fluxes in tea (Camellia sinensis) roots measured by scanning ion-selective electrode technique. Scientific Reports, 6, 1-8. https://doi.org/10.1038/srep38370

Sirousmehr, A., Arbabi, J., \& Asgharipour, M. R., (2014). Effect of drought stress levels and organic manures on yield, essential oil content and some morphological characteristics of sweet basil (Ocimum basilicum). Advances in Environmental Biology, 8, 880-890.

USDA-NRCS. (1999). Soil Taxonomy: A basic system of soil classification for making and interpreting soil surveys (2nd ed.). Natural Resources Conservation Service, U.S. Department of Agriculture. Retrieved from https://www.nrcs.usda.gov/Internet/FSE_DOCUMENTS/nrcs142p2_051232.pdf

Stefanelli, D., Goodwin, I., \& Jones, R. (2010). Minimal nitrogen and water use in horticulture: Effects on quality and content of selected nutrients. Food Research International, 43, 1833-1843. https://doi.org/10.1016/ j.foodres.2010.04.022

Taiz, L., Zeiger, E., Moller, I. M., \& Murphy, A. (2014). Plant Physiology and Development (6th ed.). Sinauer Associates Inc.

Thomasson, A. J. (1978). Towards an objective classification of soil structure. Journal of Soil Science, 29, 38-46. https://doi.org/10.1111/j.1365-2389.1978.tb02029.x 
Van Den Berg, F., Robert, C., Shaw, M. W., \& Van Den Bosch, F. (2007). Apical leaf necrosis and leaf nitrogen dynamics in diseased leaves: A model study. Plant Pathology, 56, 424-436. https://oi.org/10.1111/ j.1365-3059.2007.01565.x

Van Den Berg, F., Van Den Bosch, F., Powers, S. J., \& Shaw, M. W. (2008). Apical leaf necrosis as a defence mechanism against pathogen attack: Effects of high nutrient availability on onset and rate of necrosis. Plant Pathology, 57, 1009-1016. https://doi.org/10.1111/j.1365-3059.2008.01865.x

Viégas, I. J. M., Cordeiro, R. A. M., de Almeida, G. M., Silva, D. A., da Silva, B. C., Okumura, R. S., ... Freitas, J. M .N. (2018). Growth and visual symptoms of nutrients deficiency in mangosteens (Garcinia mangostana L.). American Journal of Plant Sciences, 9, 1014-1028. https://doi.org/10.4236/ajps.2018. 95078

Wang, X., \& Xing, Y. (2017). Evaluation of the effects of irrigation and fertilization on tomato fruit yield and quality: A principal component analysis. Scientific Reports, 7, 1-13. https://doi.org/10.1038/s41598-01700373-8

\section{Copyrights}

Copyright for this article is retained by the author(s), with first publication rights granted to the journal.

This is an open-access article distributed under the terms and conditions of the Creative Commons Attribution license (http://creativecommons.org/licenses/by/4.0/). 